\title{
IMPLEMENTASI KEBIJAKAN PROGRAM KARTU IDENTITAS ANAK (KIA) DI DINAS KEPENDUDUKAN DAN CATATAN SIPIL KABUPATEN BADUNG
}

\author{
Windi Dwi Arista \\ Universitas Pendidikan Nasional \\ windydwiarista@gmail.com \\ Wayan Suderana \\ Universitas Pendidikan Nasional \\ wsuderana@gmail.com
}

\begin{abstract}
ABSTRAK
Kementrian Dalam Negeri (Kemendagri) memberlakukan Kartu Identitas Anak (KIA) yang di harapkan menjadi Kartu Identitas bagi anak. KIA wajib dimiliki setiap anak.Hal ini tercantum dalam Peraturan Menteri Dalam Negeri No 2 Tahun2016. Tujuan KIA untuk meningkatkan Pendataan, Perlindungan, dan Pemenuhan Hak Konstitusional Warga Negara. Data yang di gunakan merupakan data primer dan data sekunder, metode pengumpulan data dalam penelitian ini yaitu menggunakan observasi, wawancara, dan dokumentasi. Analisis data menggunakan analisis deskriftif kualitatif. Hasil Penelitian dan Pembahasan Kebijakan KIA terutama dari segi tata pelaksanaannya serta hasil yang dapat di laksanakan dan diterima masyarakat. Secara fisik hasil pelaksanaan KIA telah dirasakan dengan baik dan pendistribusiannya telah merata dirasakan oleh semua golongan atau lapisan masyarakat, Namun masih banyak masyarakat yang belum mengerti akan fungsi dan manfaat KIA.
\end{abstract}

Kata Kunci: Implementasi Kebijakan, Kartu Identitas Anak (KIA), Dinas Kependudukan dan Catatan Sipil

\begin{abstract}
The Ministry of Home Affairs (Kemendagri) applies a Child Identity Card (KIA) which is expected to become an Identity Card for children. KIA must be owned by every child. This is stated in Minister of Home Affairs Regulation No. 2 of 2016. The aim of MCH is to improve Data Collection, Protection and Fulfillment of Citizens' Constitutional Rights. The data used is primary data and secondary data, data collection methods in this study are using observation, interviews, and documentation. Data analysis uses Qualitative descriptive analysis. Research
\end{abstract}


Results and Discussion of MCH Policy, especially in terms of the implementation procedures and results that can be carried out and accepted by the community. Physically the results of the implementation of $\mathrm{MCH}$ have been well felt and the distribution has been evenly felt by all groups or layers of society, but there are still many people who do not yet understand the functions and benefits of $\mathrm{MCH}$.

Keyword : Policy Implementation, Child Identity Card (KIA), Population and Civil Registry Service.

\section{Latar Belakang Masalah}

Indonesia sebagai salah satu negara dengan penduduk terbesar ke empat di dunia dengan penduduk saat ini berjumlah sekitar 246 juta jiwa saat ini, sangat mendukung pada upaya internasional untuk melihat pembangunan secara komprehensif, dengan menempatkan penduduk sebagai titik sentral perhatian. Salah satu wujud kebijakan pemerintah dalam melindungi dan mensejahterakan masyarakat serta memantau penduduk adalah kebijakan Kementerian Dalam Negeri (Kemendagri) yang mengeluarkan Peraturan Menteri Nomor 2 Tahun 2016 Tentang Kartu Identitas Anak (KIA) yang di muat dalam Undang-Undang Nomor 24 tahun 2013 Tentang Perubahan Atas Undang-Undang Nomor 23 Tahun 2006 Tentang Administrasi Kependudukan dibidang administrasi kependudukan.

Kartu ini hanya diterbitkan oleh Dinas Kependudukan dan Pencatatan Sipil Kabupaten/Kota. Penerbitan KIA bertujuan untuk meningkatkan pendataan, perlindungan, dan pemenuhan hak konstitusional warga negara. KIA memiliki dua jenis, yaitu kartu identitas untuk anak berusia 0-5 tahun dan 5-17 tahun. Syarat penerbitan, bagi anak yang baru lahir, KIA akan diterbitkan bersamaan dengan akte kelahiran. Namun, bagi anak yang belum berusia 5 tahun dan belum memiliki KIA, persyaratannya meliputi salinan kutipan akte kelahiran dan menunjukan kutipan akte kelahiran asli. Selain itu, perlu kartu keluarga orang tua atau wali dan KTP asli kedua orang tua atau wali. Anak berusia 5-17 tahun kurang satu hari, tapi belum memiliki KIA, persyaratannya adalah salinan kutipan akta kelahiran dan menunjukkan kutipan akte kelahiran asli.

Terkait dengan Kartu Identitas Anak (KIA) ini, program KIA juga telah di muat dalam Peraturan Daerah Kabupaten Badung Nomor 9 Tahun 2016 tentang Penyelenggaraan Administrasi Kependudukan. perangkat daerah terkait yang menjalankan program KIA adalah Dinas Kependudukan dan Pencatatan Sipil. Selain itu, sebagaimana diketahui bahwa 
sampai saat ini, sosialisasi akan program KIA di Kabupaten Badung sangat minim dan bahkan hampir tidak memiliki gema di tengah-tengah masyarakat. Kondisi demikian tentunya menjadi salah satu ancaman dan kendala akan efektivitas kebijakan pemerintah di Kabupaten Badung tersebut. Memang dalam berbagai penjelasan yang dikemukakan pemerintah, bahwa kartu yang berfungsi layaknya Kartu Tanda Penduduk (KTP) bagi anak di bawah 17 tahun (kurang satu hari) ini bisa digunakan untuk berbagai hal, seperti membuka tabungan di bank, kartu sehat, kartu pintar, dan lainnya atas nama sendiri, namun untuk pemanfaatan KIA seperti hal di atas masih jarang, selama ini KIA hanya di gunakan untuk fungsi pendataan saja.

Banyak terjadi pro dan kontra dalam penerbitan KIA, karena selain dinilai bertentangan dengan Undang-Undang Administrasi Kependudukan, kartu tersebut dirasa kurang memberikan dampak untuk anak, lantaran anak yang belum cakap jarang melakukan aktivitas berat di luar rumah. Padahal KIA dibuat untuk anak usia 0-17 tahun, sedangakan anak usia 0-5 tahun kebanyakan masih dibawah pengawasan orangtua dan belum memasuki sekolah dasar sehingga belum banyak membutuhkan fasilitas yang disediakan oleh adanya KIA tersebut. Selain permasalahan lainnya yang juga timbul adalah permasalahan identifikasi anak jika misalnya terjadi bencana alam dan kasus lain seperti penculikan anak. Dalam hal ini anak yang sudah memiliki KIA akan lebih mudah untuk di identifikasi karena sudah memiliki tanda pengenal yang jelas.

\section{Rumusan Masalah}

Berdasarkan penjabaran latar belakang di atas, adapun permasalahan yang dapat dirumuskan adalah bagaimana Implementasi Kebijakan Program Kartu Identitas Anak (KIA) di Dinas Kependudukan dan Catatan Sipil Kabupaten Badung?

\section{Tujuan Penelitian}

Tujuan penelitian pada artikel ini adalah Untuk mengetahui bagaimana Implementasi Kebijakan Program Kartu Identitas Anak (KIA) di Dinas Kependudukan dan Catatan Sipil Kabupaten Badung. 


\section{Kajian Teori}

\section{Teori Kebijakan Publik}

Dalam Kamus Besar Bahasa Indonesia, kebijakan diartikan sebagai rangkaian konsep dan asas yang menjadi garis besar dan dasar rencana dalam pelaksanaan suatu pekerjaan, kepemimpinan, dan cara bertindak (tentang pemerintahan, organisasi, dsb); pernyataan cita-cita, tujuan, prinsip dan garis pedoman untuk manajemen dalam usaha mencapai sasaran.

2. Teori Implementasi

Secara umum menurut Kamus Besar Bahasa Indonesia, implementasi bisa diartikan sebagai penerapan atau pelaksanaan. Istilah implementasi biasanya di kaitkan dengan suatu kegiatan yang di laksanakan untuk mnecapai tujuan tertentu. Kamus Webster, merumuskan bahwa to implement (mengimplementasikan) berarti to provide the means for carryingout (menyediakan sarana untuk melaksankan sesuatu), to give practicia effect to (menimbulkan dampak atau akibat terhadap sesuatu). Menurut Edward dalam Winarno (2012:125) Implementasi kebijakan adalah tahapan pembuat kebijakan antara pembentuk kebijakan dan konsekuensi-konsekuensi kebijakan bagi masyarakat yang di pengaruhinya ,jika suatu kebijakan tidak tepat atau tidak mengurangi masalah yang merupakan sasaran kebijakan,maka kebijakan itu mungkin akan mengalami kegagalan sekalipun kebijakan yang cemerlang mungkin juga akan mengalami kegagalan jika kebijakan tersebut kurang di implementasikan dengan baik oleh para pelaksana kebijakan.

\section{Metode Penelitian}

\section{Jenis Penelitian}

Jenis penelitian yang digunakan peneliti adalah jenis penelitian deskriptif kualitatif. Penelitian deskriptif kualitatif karena peneliti bermaksud untuk menggambarkan secara deskriptif bagaimana Implementasi Kebijakan Program Kartu Identitas Anak (KIA) di Dinas Kependudukan dan Catatan Sipil.

\section{Sumber Data}

1. Data Primer 
Data utama yang di peroleh langsung dari sumber yang berkaitan dengan penelitian yaitu dari para informan dan responden yang memiliki kompetensi dan pengetahuan untuk memberikan informasi yang di butuhkan dalam penelitian yang berkenaan dengan Implementasi Kebijakan Program Kartu Identitas Anak (KIA).

\section{Data Sekunder}

Data Sekunder adalah data yang di peroleh dari studi pustaka atau bahan informasi lain yang berhubungan dengan masalah yang akan di teliti, seperti catatan-catatan, buku-buku literature, dokumen, laporan dan sumber-sumber lain yang berhubungan dengan penelitian.

\section{Teknik Pengumpulan Data}

Teknik pengumpulan data yang di gunakan dalam penelitian adalah

1. Observasi adalah suatu cara pengumpulan data dengan dengan mengadakan pengamatan langsung terhadap suatu obyek dalam suatu periode tertentu dan mengadakan pencatatan secara sistematis tentang hal-hal tertentu yang diamati. Menurut Sugiyono (2012:139) mengemukakan bahwa, observasi merupakan proses yang kompleks, suatu proses yang tersusun dari berbagai proses biologis dan psikologis,

2. Wawancara atau interview adalah suatu bentuk komunikasi verbal, jadi semacam percakapan yang bertujuan memperoleh informasi. Menurut Esterberg dalam Sugiyono (2012:231) wawancara merupakan pertemuan dua orang untuk bertukar informasi dan ide melalui tanya jawab, sehingga dapat dikontruksikan makna dalam suatu topik tertentu. Dalam penelitian ini peneliti menggunakan wawancara berstruktur dimana sebelumnya peneliti menyiapkan daftar pertanyaan secara cermat sehingga pada saat penelitian berlangsung di Dinas Kependudukan dan Catatan Sipil Kabupaten Badung penelitian dapat melakukannya secara sistematis,

3. Dokumentasi merupakan suatu cara pengumpulan data dengan menghimpun dokumendokumen, baik dokumen tertulis, gambar, maupun elektronik. Dokumen tidak sekedar mengumpulkan dan menuliskan atau melaporkan dalam bentuk kutipan tentang sejumlah dokumen, namun yang di laporkan adalah hasil analisis terhadap dokumen-dokumen tersebut. Menurut Sugiyono (2012:240) dokumen merupakan catatan peristiwa yang sudah berlalu. Dokumentasi bisa berbentuk tulisan, gambar, atau karya-karya 
Implementasi Kebijakan Program Kartu Identitas Anak (KIA)....(W.D. Arista, Wayan Suderana)

monumental dari seseorang. Studi dokumentasi merupakan pelengkap dari penggunaan metode observasi dan wawancara dalam penelitian ini di Kabupaten Badung.

\section{Teknik Analisis Data}

Teknik analisis data merupakan data yang diperoleh melalui dokumen-dokumen, wawancara, observasi pedoman pengumpulan data dan catatan-catatan yang diperoleh dari para informan, kemudian akan dianalisis secara deskriptif kualitatif. Dalam penelitian kualitatif, proses pengumpulan data ini diawali dengan memasuki lokasi penelitian. Dalam hal ini peneliti mendatangi tempat penelitian yaitu Dinas Kependudukan dan Catatan Sipil Kabupaten Badung dengan membawa izin formal penelitian. Kemudian dilanjutkan dengan menemui informan penelitian. Lalu, pada proses selanjutnya dilakukan pengumpulan data dengan teknik wawancara dan dokumentasi untuk memperoleh informasi yang dibutuhkan dengan lengkap yang diperoleh dilapangan. Setelah data terkumpul maka di akan dianalisis dengan beberapa teknik analisis data. Adapun tahap-tahap teknik analisis dalam penelitian ini adalah sebagai berikut:

\section{Reduksi data}

Reduksi data merupakan pemilihan data atau seleksi dan pemusatan perhatian kepada data-data yang betul betul dibutuhkan sebagai data utama dan juga data yang sifatnya hanya pelengkap saja. Data yang di peroleh dari lokasi penelitian atau data lapangan dituangkan dalam uraian atau laporan yang lengkap dan terperinci. Laporan lapangan direduksi, dirangkum, dipilih hal-hal yang pokok, difokuskan pada hal-hal yang penting.

2. Penyajian data

Penyajian data merupakan rangkaian organisasi informasi yang memungkinkan penelitian dilakukan. Penyajian data diperoleh dengan berbagai jenis, jaringan kerja, keterkaitan kegiatan atau tabel.

3. Penarikan Kesimpulan

Setelah melakukan penyajian data maka kesimpulan awal dapat dilakukan. Penarikan kesimpulan ini juga dilakukan selama penelitian berlangsung. Sejak awal kelapangan 
serta dalam proses pengumpulan data peneliti berusaha melakukan analisis dan mencari makna dari yang telah terkumpulkan.

\section{Hasil Penelitian dan Pembahasan}

Dapat di simpulkan hasil penelitian dari tata pelaksaan program KIA ini Kejelasan program KIA yang dilaksanakan oleh Dinas Kependudukan dan Catatan Sipil Kabupaten Badung sudah baik sejalan dengan hal tersebut kelengkapan sarana dan prasaran dalam pembuatan KIA sudah terpenuhi dengan baik, Program KIA telah terlaksana baik dari segi hasil, procedure, sarana prasarana dan waktu. Hasil yang dikemukakan oleh para informan telah menunjukkan perbaikan menuju peningkatan. Prosedur mengenai KIA ini sudah dikatakan sederhana, kesederhanaan yang dimaksud adalah prosedur atau tatacara pelaksaannya mudah, lancar, cepat, tepat, tidak berbelit belit, mudah di pahami dan mudah di laksanakan oleh masyarakat. Adanya prosedur tidak di maksudkan untuk mempersulit atau bahkan menghambat pelaksanaan kebijakan. Prosedur yang sederhana tentunya akan mempermudah segala kegiatan pelaksanaan kebijakan guna mencapai tujuan tercapainya tertib administrasi. Walupun masih terdapat kekeliruan data seperti alamat, tahun lahir, namun hal tersebut dapat ditanggulangi dengan melakukan penerbitan KIA yang telah direvisi oleh pihak terkait dalam hal ini yaitu Dinas Kependudukan dan Catatan Sipil.

Dalam segi pembiayaan Sekretaris Dinas mengaskan bahwa semua biaya yang dikeluarkan adalah wewenang pemerintah pusat dalam hal ini adalah Kemendagri yang menganggarkan adalah pemerintah daerah. Kebijakan KIA terutama dari segi tata pelaksanaannya serta hasil yang dapat di laksanakan dan diterima masyarakat. Secara fisik hasil pelaksanaan KIA telah dirasakan dengan baik dan pendistribusiannya telah merata dirasakan oleh semua golongan atau lapisan masyarakat, sehingga dengan informasi yang tepat dan akurat masyarakat dapat mengerti akan prosedur dan tata cara pembuatan KIA serta mendapatkan hasil yang sesuai dengan harapan. Namun yang menjadi catatan adalah bahwa terdapat sebagian kecil masyarakat yang belum mengerti akan fungsi dan Pemanfaatan dari KIA ini, sehingga penjelasan lebih lanjut harus dilakukan aparatur yang berwenang dan berkompeten untuk menjelaskan fungsi dari KIA ini. 
Selain itu daya tanggap petugas dalam melayani pembuatan KIA, yang dirasakan oleh masyarakat masih terdapat masyarakat yang mengeluhkan lambannya pelayanan KIA tersebut, serta belum ada petugas yang mengarahkan ketika mereka hendak mengikuti procedure pembuatan KIA, sehingga masyarakat perlu bertanya terlebih dahulu. Namun dalam pengamatan yang berbeda petugas cukup tanggap terhadap masyarakat yang memiliki kebutuhan khusus. Dapat di katakan yang dilakukan dalam prosedur pembuatan KIA pada Dinas Kependudukan dan Catatan Sipil Kabupaten Badung dapat dikatakan sudah berjalan baik dan sederhana. Urutanurutan dan langkah-langkah yang harus di lewati masyarakat sebagai pemohon tidak terlalu rumit. Selain itu, kegiatan pelayanan hanya pada satu bagian pelayanan saja yaitu di bagian pelayanan kependudukan sehingga tidak membingungkan masyarakat dan persyaratan yang di berikan tidak memberatkan masyarakat. Selain itu pada dasarnya para petugas yang ada di Dinas Kependudukan dan Catatan Sipil Kabupaten Badung telah berusaha memberikan pelayanan yang memuaskan kepada pemohon dan berusaha semaksimal mungkin memberikan kesan bahwa mengurus KIA tidaklah rumit,asalkan dari pihak pemohon sendiri mau turut berperan serta di dalamnya, yaitu dengan melengkapi persyaratan yang di butuhkan dan bersedia memberikan data yang sebenar-benarnya.

\section{Kesimpulan}

Implementasi kebijakan KIA oleh Dinas Kependudukan dan Pencatatan Sipil Kabupaten Badung telah sesuai dengan ketentuan/prosedur yang telah ditetapkan. Hasil penelitian di lapangan tentang verifikasi dan validasi data menunjukkan bahwa pelaksanaan pendataan dengan tahapan yang telah ditentukan tersebut (SPO) telah dilaksanakan dengan sangat baik oleh petugas. Petugas nampak cukup lugas dan tidak canggung melakukan pekerjaannya melayani penduduk yang di data personalnya tersebut. Pengamatan penulis dalam pendataan penduduk, petugas membutuhkan sekitar 5 menit untuk dapat menyelesaikan perekaman data satu orang

penduduk. Dari segi kemampuan SDM nya segi kuantitas, dirasakan bahwa telah cukup untuk mendukung terlaksananya program KIA.

Baik dalam proses sosialisasi, pendataan dan proses pengambilan nantinya. Sedang dari segi kualitas, pegawai mempunyai latar belakang pengalaman dan pendidikan yang baik. Sarana Prasarana menunjukkan bahwa dari sisi jumlah tersedianya sarana dan prasarana tersebut dapat 
dikatakan tersedia dengan baik dan dapat menunjang pelaksanaan pendataan penduduk. Namun dari hasil wawancara terkadang mengalami hambatan karena masalah sistem aplikasi di komputer dan jaringan networking yang bermasalah. Selain itu masalah lain adalah suply listrik jika terjadi pemadaman, karena peralatan inti ini membutuhkan suply listrik yang stabil. Dan terkait dengan pemanfaatan KIA yang di berikan oleh Dinas Kependudukan Dan Catatan Sipil Kabupaten Badung belum maksimal dan tidak dapat terlaksana dengan baik karena masyarakat masih banyak belum paham dengan fungsi dan manfaat KIA tersebut.

\section{Daftar Pustaka}

Buku :

Abdul Wahab, Solichin. 2016. Analisis Kebijakan dari Formulasi ke Penyusunan Model-model Implementasi Kebijakan Publik. Edisi Kelima. Jakarta: PT. Bumi Aksara.

Moleong, J. Lexy. 2012.Metodologi Penelitian Kualitatif. Bandung: PT Remaja Rosdakarya.

Subarsono, AG. 2011. Analisis Kebijakan Publik Konsep Teori dan Aplikasi. Yogyakarta: Pustaka Pelajar.

Sugiyono. 2012. Memahami Penelitian Kualitatif'. Bandung : ALFABETA.

Sugiyono. 2010. Metode Penelitian Pendidikan Pendekatan Kuantitatif, kualitatif, dan R\&D. Bandung: Alfabeta.

Suharno 2010. Dasar-Dasar Kebijakan Publik. Yogyakarta: UNY Press.

Winarno. 2012. Kebijakan Publik Teori, Proses, dan Studi Kasus. Yogyakarta: CAPS. 
Implementasi Kebijakan Program Kartu Identitas Anak (KIA)....(W.D. Arista, Wayan Suderana)

\section{Jurnal :}

Afrizal,Chandy. 2017.Pelaksanaan Kebijakan Pembuatan Kartu Identitas Anak Di Kota Bandar Lampung,Journal of Human Resource Planing, p 143-190.

Fradika,Eri. 2018.Implementasi Kebijakan Kartu Identitas Anak Di Dinas Kependudukan Dan Pencatatan Sipil Kota Yogyakarta. Journal of Human Resource Planing, p 123-140.

\section{Skripsi :}

Anggraeni,D.M \& Saryono. 2011. Metodelogi Penelitian Kualitatif dan Kuantitatif dalam Bidang Kesehatan.Yogyakarta: Nuha Medika.

Anggreani,Wulan. 2017. Implementasi Administrasi Kependudukan Terhadap Kepuasan Masyarakat dan Kualitas Pelayanan E-KTP. Skripsi, Program Sarjana Studi Administrasi Negara, Fakultas Ilmu Sosial dan Ilmu Politik Universitas Pendidikan Nasional Denpasar.

Fradika,Eri. 2018. Implementasi Kebijakan Kartu Identitas Anak Di Dinas Kependudukan Dan Pencatatan Sipil Kota Yogyakarta. Skripsi,Program Study Strata satu(S1) Ilmu Pemerintah, Sekolah Tinggi Pembangunan Masyarakat Desa “APMD” Yogyakarta.

Terawati. 2017. Pengaturan Administrasi Kependudukan Terkait Pemberlakuan Permendagri Nomor 2 Tahun 2016 tentang Kartu Identitas Anak. Skripsi,Program Sarjana Hukum Administrasi Negara. Fakultas Hukum Universitas Lampung,Bandar Lampung.

\section{Internet :}

Dispendukcapil, Kabupaten Grobogan. 2016. Kartu Identitas Anak (online). Available http://dispendukcapil.grobogan.go.id/kartu-identitas-anak-kia (19 agustus 2018).

Kemendagri, Kabupaten Badung. 2016. Peraturan Daerah Kabupaten Badung (online). Available http://www.jdih.setjen.kemendagri.go.id/files/KAB_BADUNG_9_2016.pdf (18 agustus 2018). 
Undang-Undang Republik Indonesia. 2013. Undang-Undang Republik Indonesia Nomor 24 Tahun 2013 tentang perubahan atas Undang-Undang nomor 23 tahun 2006 tentang Administrasi Kependudukan (online). Available http://dukcapil.kemendagri.go.id/izCFiles/uploads/downloads/UU_24_Thn_20132.pdf 